\title{
Carbonea vitellinaria new to Japan, with a key to lichenicolous fungi growing on species of Candelariella
}

\author{
Ohmura $\mathrm{Y}^{1}$, Yakovchenko $\mathrm{L}^{2,3}$ and Zhurbenko $\mathrm{MP}^{4}$ \\ ${ }^{1}$ Department of Botany, National Museum of Nature and Science, Amakubo 4-1-1, Tsukuba, Ibaraki, 305-0005, Japan. \\ E-mail: ohmura-y@kahaku.go.jp \\ ${ }^{2}$ Institute of Biology and Soil Science FEB RAS, Stoletiya Vladivostoka Avenue, 159, Vladivostok, 690022, Russia \\ ${ }^{3}$ Botanical Garden-Institute FEB RAS, Makovskogo st., 142, Vladivostok, 690024, Russia \\ ${ }^{4}$ Laboratory of the Systematics and Geography of Fungi, Komarov Botanical Institute, Russian Academy of Sciences, \\ Professor Popov 2, St.-Petersburg, 197376, Russia
}

Ohmura Y, Yakovchenko L, Zhurbenko MP 2014 - Carbonea vitellinaria new to Japan, with a key to lichenicolous fungi growing on species of Candelariella. Mycosphere 5(5), 607-611, Doi 10.5943/mycosphere/5/5/1

\begin{abstract}
Carbonea vitellinaria is reported new to Japan growing on Candelariella vitellina. A key to lichenicolous fungi known on the species of Candelariella is provided.

Key words - biogeography - Candelariella vitellina - parasite

\section{Introduction}

Reports of lichenicolous fungi from Japan are still very fragmentary (e.g. Tibell \& Thor 2003, Kurokawa \& Kashiwadani 2006, Frisch \& Ohmura 2013), not including many presumably common species. This contribution deals with one such species newly reported for Japan from Candelariella vitellina, also providing a key to lichenicolous fungi known to grow on species of this host lichen genus.
\end{abstract}

\section{Materials \& Methods}

A total of 83 Japanese specimens of Candelariaceae housed in the National Museum of Nature and Science (TNS), Tsukuba, were checked.

Morphological observations were made using a dissecting microscope or a differential interference contrast microscope. Anatomical examinations were made using hand-cut sections mounted in GAW (glycerin: ethanol: water $=1: 1: 1$ ). Ascus apex structure was observed in $0.5 \%$ Lugol's iodine solution with pretreatment of $10 \% \mathrm{KOH} \mathrm{(K/I)} \mathrm{(Smith} \mathrm{et} \mathrm{al.} \mathrm{2009).} \mathrm{Spore}$ measurements are given as (minimum-)average (-maximum) (SD = standard deviation; $n=$ number of measurements).

\section{Results \& Discussion}

Carbonea vitellinaria (Nyl.) Hertel, Mitt. bot. StSamml., Münch. 19: 442 (1983). $\quad$ Fig. 1A Specimen examined. JAPAN, Honshu, Prov. Kozuke (Pref. Gunma), between Oyamasawatashiro and Mt. Koshibutsu, Katashina-mura, Tone-gun, $36^{\circ} 53^{\prime} \mathrm{N}, 139^{\circ} 10^{\prime} \mathrm{E}$, elev. ca. 2100 m, on Candelariella vitellina on rock, 9 October 2001, H. Kashiwadani 44328 (TNS). 

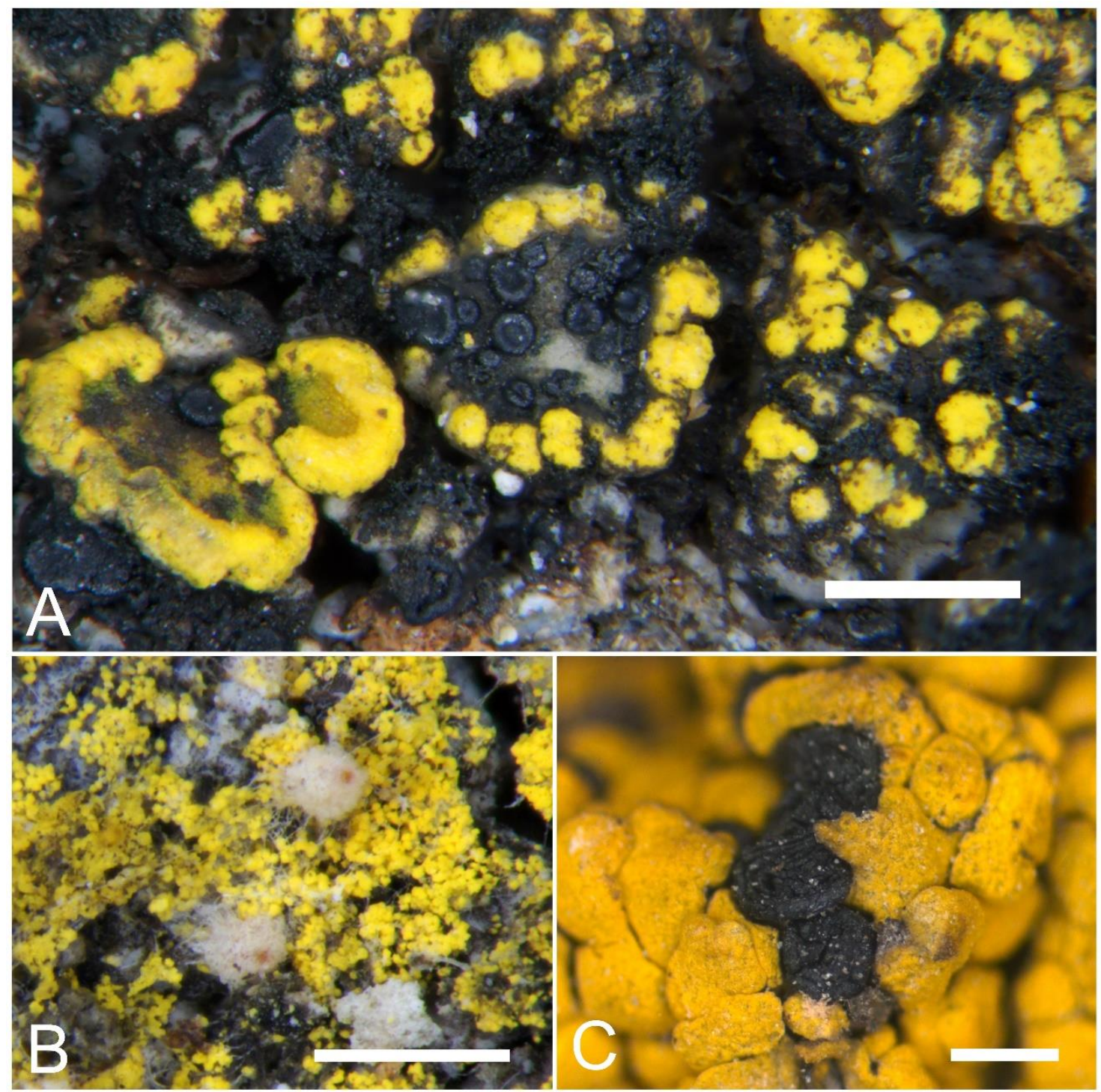

Fig. 1 - Some representative lichenicolous fungi on Candelariaceae. A. Carbonea vitellinaria (H. Kashiwadani 44328, TNS). B. Paranectria oropensis (R. Santesson: Fungi Lichenicoli Exsiccati 214, TNS). C. Sarcogyne sphaerospora (M. Zhurbenko 1323, LE 260996). Bars $=0.5 \mathrm{~mm}$.

Morphological and chemical features of the Japanese material fit with the descriptions provided by Knoph et al. (2004) and Chambers et al. (2009). The statistical values of morphological features for the Japanese material are as follows. Apothecia up to $0.27 \mathrm{~mm}$ diam.; margin up to $40 \mu \mathrm{m}$ thick; ascospores $\left(8.0^{-}\right) 9.0(-11.0) \times\left(4.0^{-}\right) 4.9(-5.5) \mu \mathrm{m}(\mathrm{SD}=1.0,0.5 ; n=12)$.

Generally Carbonea vitellinaria is a very common parasymbiotic dweller of Candelariella species with cosmopolitan distribution, known from Europe, North and South America, Oceania, and Asia (e.g. Hertel \& Zhao 1982, Obermayer 2004, Galloway 2007, Etayo \& Sancho 2008, Chambers et al. 2009, Zhurbenko 2009). However, this species seems to be rare in Japan since just one of 83 examined specimens of Candelariaceae collected from Hokkaido to Kyushu (elevations 5-2700 m) was infected by the parasite. In addition, no other lichenicolous fungi were found on those specimens. Carbonea vitellinaria has also been reported from lichen species of Lecanora, Lecidea s. 1., Rhizocarpon, Tephromela and Toninia, mainly growing on non-calciferous rocks (Clauzade et al. 1989, Knoph et al. 2004, Zhurbenko 2009). This is the first non-lichenized lichenicolous species of Carbonea found in Japan, all previously known ones, viz. C. atronivea (Arnold) Hertel, C. latypizodes (Nyl.) Knoph \& Rambold, and C. vorticosa (Flörke) Hertel (Inoue \& Moon 1995, Kurokawa \& Kashiwadani 2006, Inoue \& Kanda 2009), are autonomous lichens. 


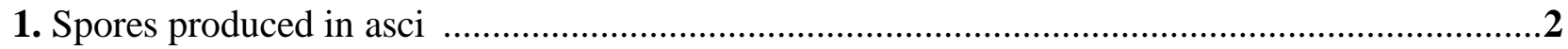

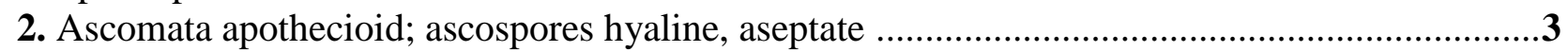

3. Asci with more than 8 spores

4. Ascospores globose to broadly ellipsoid, $\left(3^{-}\right) 4-5(-6) \times(3-) 3.5-4(-4.5) \mu \mathrm{m}$. See Lendemer et al. (2009) and Zhurbenko (2013) Sarcogyne sphaerospora J. Steiner 4*. Ascospores narrowly to broadly ellipsoid, $\left(3^{-}\right) 4-4.5(-5) \times(1-) 1.5-2(-3) \mu \mathrm{m}$. See Knudsen \& Kocourkova (2008)..... .Polysporina subfuscescens (Nyl.) K. Knudsen \& Kocourk. 3*. Asci 8-spored; ascospores ellipsoid or obovoid, 6-12(-13) $\times 4-7 \mu \mathrm{m}$. See Knoph et al. (2004) Carbonea vitellinaria (Nyl.) Hertel

2*. Ascomata perithecioid; ascospores brown, septate .5

5. Asci with 64-100 spores; ascospores (4.5-)5-6(-7) $\times(2-) 2.5-3(-3.5) \mu \mathrm{m},(0-) 1$-septate. See Triebel (1989) and Vondrák \& Etayo (2007).......Muellerella lichenicola (Sommerf.) D. Hawksw. 5*. Asci 2-8-spored .6

6. Ascospores brown, 1-septate; interascal filaments absent.....................................................

7. Ascomata (100-)150-200(-400) $\mu \mathrm{m}$ in diam.; asci (4-)8-spored; ascospores (7.5-)8.5-12.5(-13) $\times 5-7(-7.5) \mu \mathrm{m}$. See Triebel (1989) and Coppins (2000)

Endococcus propinquus (Körb.) D. Hawksw.

7*. Ascomata 160-190 $\mu \mathrm{m}$ in diam.; asci 4-spored; ascospores 12.5-17 × 5-7 $\mu \mathrm{m}$. See Vondrák et al. (2008)

Endococcus sp.

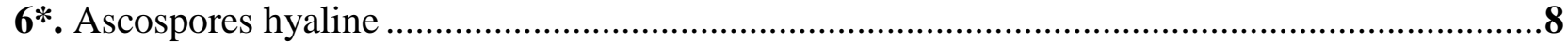

8. Asci with dimorphic, 1(-2)-septate spores, macroascospores $34-50(-60) \times 12-18(-20) \mu \mathrm{m}$, microascospores 8-17 $\times 3.5-7 \mu \mathrm{m}$; ascomata superficial, pink to orangish, clothed with white hair-like hyphae. See Hawksworth \& Booth (1976) and Flakus et al. (2006)

8*. Ascospores monomorphic

Ovicuculispora parmeliae (Berk. \& Curt.) Etayo

9. Ascospores muriform, ellipsoid, bicaudate, body $(22-) 25-32(-36) \times(9-) 11-14(-15) \mu \mathrm{m}, 2-8$ per ascus; ascomata superficial, hairy. See Hawksworth (1982), Santesson (1994) and van den Boom \& van den Boom (2006)

Paranectria oropensis (Ces.) D. Hawksw. \& Piroz.

9*. Ascospores 0(-1)-septate, oblong to obovoid, non-caudate, (11-)12.6-19.4(-20.5) × (5.5-)68.6(-10) $\mu \mathrm{m},(6-) 8$ per ascus; ascomata semi-immersed, hairless. See Hoffmann \& Hafellner (2000) and Halici \& Aksoy (2009)... Zwackhiomyces lecanorae (Stein) Nik. Hoffm. \& Hafellner [Note also a slightly lichenized lichenicolous pyrenomycete Sarcopyrenia cylindrospora (P. Crouan \& H. Crouan) M. B. Aguirre, occurring on Candelariella species. The fungus is characterized by large, finally sessile perithecia, evanescent paraphyses, 8-spored, unitunicate asci, hyaline, bacilliform with rounded ends, 1-septate ascospores, measuring 24-35 $\times 2.5-3 \mu \mathrm{m}$, and distinct pathogenicity (Calatayud \& Barreno 1994, Kocourková 2000).]

$1 *$ Spores not produced in asci .

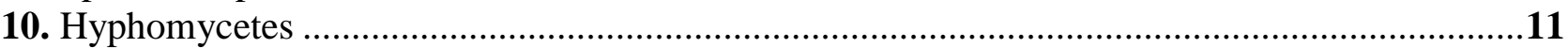

11. Colonies superficial, arising in dark brown to almost black caespitose tufts of straight conidiophores, 15-30(-50) $\times 3.5-6 \mu \mathrm{m}$; conidia acrogenous, brown, doliiform, 1(-2)-septate, 7$11 \times 3.5-5(-6) \mu \mathrm{m}$, mostly adhering in chains. See Hawksworth (1979).

Taeniolella delicata M.S. Christ. \& D. Hawksw.

11*. Colonies immersed in the hymenium of the host apothecia, which usually become darkened in the presence of the fungus; conidia developing at the surface of the host hymenium. See Hawksworth (1979), Diederich (1990) and Hawksworth \& Cole (2002) ......................................12

12. Conidia 0(-1)-septate, brownish, subspherical to ellipsoid, $3-4.5 \times 2.5-4 \mu \mathrm{m}$, adhering in chains.... Intralichen lichenum (Diederich) D. Hawksw. \& M.S. Cole

12*. Conidia always septate 13

13. Conidia 1-septate, pale brown, ellipsoid to doliiform, 5-8(-9) $\times 4-6 \mu \mathrm{m}$, adhering in chains..... Intralichen christiansenii (D. Hawksw.) D. Hawksw. \& M.S. Cole 
13*. Conidia 2 to multi-septate to muriform, dark brown, subcylindrical to irregularly ellipsoid, mainly $18-25 \times 6-12 \mu \mathrm{m}$, solitary or adhering in chains

Intralichen lichenicola (M.S. Christ. \& D. Hawksw.) D. Hawksw. \& M.S. Cole

$10 *$. Basidiomycetes

14. Fructifications of subspherical or irregular pinkish or reddish bulbils up to $250 \mu \mathrm{m}$ in diam., initially developing inside the lichen thallus, later erumpent and superficial, composed of subspherical to elongate, catenate cells. See Diederich \& Lawrey (2007) and Kocourková (2000)

Marchandiomyces corallinus (Roberge) Diederich \& D. Hawksw.

14*. Fructifications of basidiomata developing on swollen, bright yellow, pruinose galls on the host thallus; hymenium of numerous paraphyses-like hyphae intermixed with the basidia, covered by a 20-50 $\mu \mathrm{m}$ thick orange to brownish layer of crystals. See Diederich (1996)

Tremella candelariellae Diederich \& Etayo

\section{Acknowledgements}

We thank an anonymous reviewer and Kerry Knudsen for valuable comments on the manuscript. This study was supported by JSPS KAKENHI Grant no. 24300314 to YO and by grant from the Russian Foundation for Basic Research no. 13-04-01453 to LY.

\section{References}

Calatayud V, Barreno E. 1994 - Contribution to the lichen floristics of eastern Spain - I. Silicicolous lichens and their lichenicolous fungi of Serra d'Espadà (Castelló). Cryptogamie, Bryologie-Lichénologie 15, 23-41.

Chambers SP, Galloway DJ, James PW. 2009 - Carbonea (Hertel) Hertel (1983). In: The lichens of Great Britain and Ireland (eds CW Smith, A Aptroot, BJ Coppins, A Fletcher, OL Gilbert, PW James, PA Wolseley). The British Lichen Society, London, pp. 278-280.

Clauzade G, Diederich P, Roux C. 1989 - Nelikenigintaj fungoj likenlogaj. Ilustrita determinlibro. Bulletin de la Société Linnéenne de Provence, Numero Special 1, 1-142.

Coppins BJ. 2000 - New, rare and interesting British lichen and lichenicolous fungus records. British Lichen Society Bulletin 86, 42-56.

Diederich P. 1990 - New or interesting lichenicolous fungi 1. Species from Luxembourg. Mycotaxon 37, 297-330.

Diederich P. 1996 - The lichenicolous Heterobasidiomycetes. Bibliotheca Lichenologica 61, 1198.

Diederich P, Lawrey JD. 2007 - New lichenicolous, muscicolous, corticolous and lignicolous taxa of Burgoa s. 1. and Marchandiomyces s. 1. (anamorphic Basidiomycota), a new genus for Omphalina foliacea, and a catalogue and a key to the non-lichenized, bulbilliferous basidiomycetes. Mycological Progress 6, 61-80.

Etayo J, Sancho LG. 2008 - Hongos liquenícolas del sur de Sudamérica, especialmente de Isla Navarino (Chile). Bibliotheca Lichenologica 98, 1-302.

Flakus A, Kukwa M, Czarnota P. 2006 - Some interesting records of lichenized and lichenicolous Ascomycota from South America. Polish Botanical Journal 51, 209-215.

Frisch A, Ohmura Y. 2013 - Opegrapha phaeophysciae (Opegraphaceae, Arthoniomycetes), a lichenicolous ascomycete, new to Japan. Bulletin of the National Museum of Nature and Science, Series B 39, 11-14.

Galloway DJ. 2007 - Flora of New Zealand: Lichens, including lichen-forming and lichenicolous fungi. Revised second edition. Vol. 1. Lincoln, Manaaki Whenua Press. 1006 pp.

Halici MG, Aksoy A. 2009 - Lichenised and lichenicolous fungi of Aladağlar National Park (Niğde, Kayseri and Adana provinces) in Turkey. Turkish Journal of Botany 33, 169-189.

Hawksworth DL. 1979 - The lichenicolous hyphomycetes. Bulletin of the British Museum (Natural History), Botany Series 6, 183-300. 
Hawksworth DL. 1982 - Notes on British lichenicolous fungi: IV. Notes from the Royal Botanical Garden Edinburgh 40, 375-397.

Hawksworth DL, Booth C. 1976 - Some observations on Nectria heterospora. Mycologia 68, 195200.

Hawksworth DL, Cole MS. 2002 - Intralichen, a new genus for lichenicolous 'Bispora' and 'Trimmatostroma' species. Fungal Diversity 11, 87-97.

Hertel H, Zhao, CF. 1982 - Lichens from Changbai Shan - some additions to the lichen flora of North-East China. Lichenologist 14, 139-152.

Hoffmann N, Hafellner J. 2000 - Eine Revision der lichenicolen Arten der Sammelgattungen Guignardia und Physalospora (Ascomycotina). Bibliotheca Lichenologica 77, 1-181.

Inoue M, Kanda H. 2009 - Distribution patterns of Japanese lecideoid lichens occurring in subalpine or alpine regions, with special reference to the taxa being distributed in both Japan and Svalbard. Memoirs of the Faculty of Education and Human Studies, Akita University (Natural Science) 64, 1-8.

Inoue M, Moon KH. 1995 - Lichens of Shirakami-sanchi, northern Japan. In: Kokuritsu koen kyokai (ed.): Shirakami sanchi shizen kankyo hozen chiiki sogo chosa hokokusho, pp. 233247 (in Japanese).

Knoph JG, Rambold G, Triebel D, Kainz C. 2004 - Carbonea. In: Lichen Flora of the Greater Sonoran Desert Region, Vol. 2. (eds TH III Nash, BD Ryan, P Diederich, C Gries, F Bungartz). Lichens Unlimited, Arizona State University, Tempe, Arizona, pp. 54-55.

Knudsen K, Kocourkova J. 2008 - A study of lichenicolous species of Polysporina (Acarosporaceae). Mycotaxon 105, 149-164.

Kocourková J. 2000 [1999] - Lichenicolous fungi of the Czech Republic (the first commented checklist). Acta Musei Nationalis Pragae, Series B, Historia Naturalis 55(3-4), 59-169.

Kurokawa S, Kashiwadani H. 2006 - Checklist of Japanese lichens and allied fungi. National Science Museum Monographs 33, 1-157.

Lendemer JC, Kocourková J, Knudsen K. 2009 - Studies in lichen and lichenicolous fungi: more notes on taxa from North America. Mycotaxon 108, 491-497.

Obermayer W. 2004 - Additions to the lichen flora of the Tibetan region. Bibliotheca Lichenologica 88, 479-526.

Santesson R. 1994 - Fungi lichenicoli exsiccati. Fasc. 9 \& 10 (nos. 201-250). Thunbergia 22, 1-24.

Smith CW, Aptroot A, Coppins BJ, Fletcher A, Gilbert OL, James PW, Wolseley PA (eds). 2009 The lichens of Great Britain and Ireland. The British Lichen Society, London. 1046 pp.

Tibell L, Thor G. 2003 - Calicioid lichens and fungi of Japan. Journal of the Hattori Botanical Laboratory 94, 205-259.

Triebel D. 1989 - Lecideicole Ascomyceten. Eine Revision der obligat lichenicolen Ascomyceten auf lecideoiden Flechten. Bibliotheca Lichenologica, 1-278.

van den Boom P, van den Boom B. 2006 - An inventory of lichens and lichenicolous fungi in northern Belgium (area of Stramprooierbroek). Bulletin de la Société Naturalistes Luxembourgeois 106, 39-52.

Vondrák J, Etayo J. 2007 - A contribution to the diversity of lichen-forming and lichenicolous fungi in the Spanish Pyrenees. Herzogia 20, 189-198.

Vondrák J, Guttová A, Mayrhofer H. 2008 - A further contribution to the knowledge of lichenforming and lichenicolous fungi in Crete. Herzogia 21, 105-124.

Zhurbenko MP. 2009 - Lichenicolous fungi and lichens from the Holarctic. Part II. Opuscula Philolichenum 7, 121-186.

Zhurbenko MP. 2013 - A first list of lichenicolous fungi from India. Mycobiota 3, 19-34. 